\title{
Formation of Nanosilver from Silver Sulfide Nanoparticles in Natural Waters by Photoinduced Fe(II, III) Redox Cycling
}

\author{
Lingxiangyu Li, ${ }^{\dagger}$ Qunfang Zhou, ${ }^{\dagger}$ Fanglan Geng, ${ }^{\dagger}$ Yawei Wang, ${ }^{*},{ }^{\dagger}, \AA$ and Guibin Jiang ${ }^{\dagger}$ \\ ${ }^{\dagger}$ State Key Laboratory of Environmental Chemistry and Ecotoxicology, Research Center for Eco-Environmental Sciences, Chinese \\ Academy of Sciences, Beijing 100085, China \\ \#Institute of Environment and Health, Jianghan University, Wuhan 430056, China \\ ${ }^{\S}$ University of Chinese Academy of Sciences, Beijing 100049, China
}

\section{Supporting Information}

ABSTRACT: Nanosilver ( $\mathrm{nAg}$ ) has been repeatedly demonstrated to end up as silver sulfide nanoparticles ( $\left.\mathrm{Ag}_{2} \mathrm{SNPs}\right)$, but little is known about the potential transformations of $\mathrm{Ag}_{2} \mathrm{SNPs}$ in natural environments that are very important for comprehensive assessments of $\mathrm{nAg}$ risks to human and environmental health. Here we show that $\mathrm{Ag}_{2} \mathrm{SNPs}$ can release tiny amounts of silver ion via cation exchange reactions between $\mathrm{Ag}(\mathrm{I})$ and $\mathrm{Fe}(\mathrm{III})$ in the dark, while in the light dramatic dissolution of $\mathrm{Ag}_{2} \mathrm{SNP}$ occurs, which is mainly attributed to the $\mathrm{Ag}_{2} \mathrm{SNP}$ oxidation by the hydroxyl radical formed during the reduction of $\mathrm{Fe}$ (III) to $\mathrm{Fe}$ (II) in water under sunlit conditions. However, silver ions are subsequently reduced to $\mathrm{nAg}$ in the light due to the strong reducing power of $\mathrm{Fe}(\mathrm{II})$. Thus, the

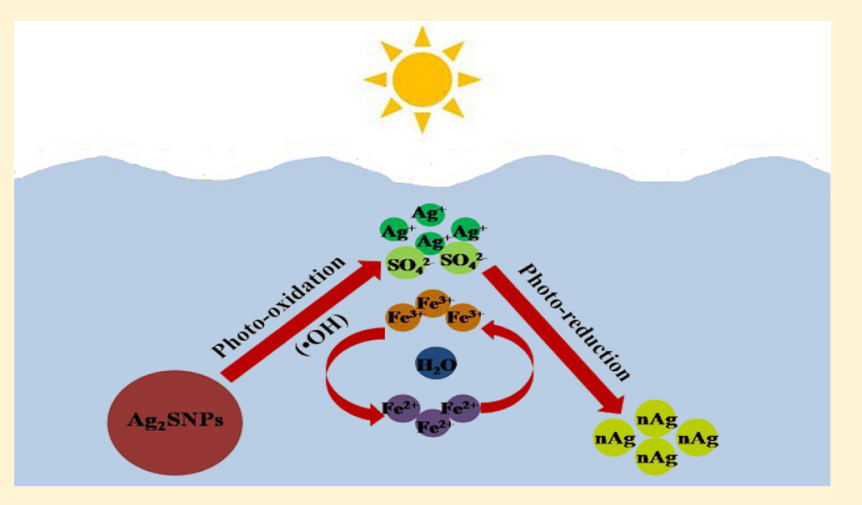
formation of $\mathrm{nAg}$ from $\mathrm{Ag}_{2} \mathrm{SNPs}$ in the presence of $\mathrm{Fe}(\mathrm{III})$ under light conditions proceeds through a two-step reaction mechanism, the photoinduced and $\mathrm{Fe}$ (III)-dependent dissolution of $\mathrm{Ag}_{2} \mathrm{SNPs}$, followed by the reduction of silver ions to $\mathrm{nAg}$ by $\mathrm{Fe}(\mathrm{II})$. The formation of $\mathrm{nAg}$ from $\mathrm{Ag}_{2} \mathrm{SNPs}$ is also validated in environmental waters under light conditions. It is thus concluded that photoinduced $\mathrm{Fe}(\mathrm{III}) / \mathrm{Fe}$ (II) redox cycling can drive the formation of $\mathrm{nAg}$ from $\mathrm{Ag}_{2} \mathrm{SNPs}$ in natural waters. These findings suggest that the previous consensus about the stability of $\mathrm{Ag}_{2} \mathrm{SNPs}$ in aquatic environments should be reconsidered.

\section{INTRODUCTION}

Nanosilver ( $\mathrm{nAg}$ ) is being widely used in commercial products, which can release $\mathrm{nAg}$ to the environment during the manufacturing, use and disposal of these products. ${ }^{1-3} \mathrm{nAg}$ has been shown to readily undergo sulfidation, ${ }^{4-9}$ which transforms $\mathrm{nAg}$ to highly insoluble and stable silver sulfide nanoparticles $\left(\mathrm{Ag}_{2} \mathrm{SNPs}\right),{ }^{10-13}$ reducing the toxicity of $\mathrm{nAg}$ to organisms such as Escherichia coli., least duckweed, nematode worm, zebrafish, and killifish. ${ }^{14,15}$ Consequently, there is an emerging consensus that the use of $\mathrm{nAg}$ is unlikely to impose risks on human and environmental health due to the existence of sulfidation as a natural and ultimate antidote. ${ }^{10-19}$ Given precautionary principles, however, some uncertainties remain as follow: Are they truly stable? Can silver be remobilized from $\mathrm{Ag}_{2} \mathrm{SNPs}$ under environmental conditions? If so, how can transformations of $\mathrm{Ag}_{2} \mathrm{SNPs}$ occur in natural environments? These concerns are very important for scientists to fully understand the risks of $\mathrm{nAg}$ to human and environmental health.

$\mathrm{Ag}_{2}$ SNPs were reported to be chemically stable and have profoundly low silver lability over an incubation period of several months in soils or composting sludge. ${ }^{10-13,16}$ However, a recent study showed that rapid oxidation of $\mathrm{Ag}_{2} \mathrm{SNP}$ can occur in wastewater effluent treated by ozone, along with the release of silver ions and particularly a change in species, resulting in an increase in their acute toxicity to green algae. ${ }^{20}$ Our study has shown that light irradiation also influences the stability of $\mathrm{Ag}_{2} \mathrm{SNPs}$ in water containing $\mathrm{Fe}(\mathrm{III}),{ }^{21}$ indicating that light and $\mathrm{Fe}$ (III) probably have the potential to drive $\mathrm{Ag}_{2}$ SNPs transformations. Nevertheless, the potential pathways and mechanisms for the transformations of $\mathrm{Ag}_{2} \mathrm{SNPs}$ in natural waters are unknown, representing an uncertainty of their risks to the environment and, on a larger scale, to human health.

Herein we fully investigate the pathway and mechanism for transformations of $\mathrm{Ag}_{2} \mathrm{SNPs}$ in water with an environmentally relevant concentration of $\mathrm{Fe}$ (III) under both light and dark conditions. We propose that the transformation of $\mathrm{Ag}_{2} \mathrm{SNPs}$ in the presence of $\mathrm{Fe}(\mathrm{III})$ under light conditions proceeds through a two-step reaction mechanism, the photoinduced and $\mathrm{Fe}$ (III)-dependent oxidation of $\mathrm{Ag}_{2} \mathrm{SNP}$, followed by the reduction of silver ions to $\mathrm{nAg}$ by $\mathrm{Fe}(\mathrm{II})$. We further exploit this mechanism in natural waters including landscape water, wastewater treatment plant effluent and river water, confirming

Received: August 10, 2016

Revised: November 1, 2016

Accepted: November 13, 2016

Published: November 14, 2016 
that the formation of $\mathrm{nAg}$ from $\mathrm{Ag}_{2} \mathrm{SNPs}$ can indeed occur. Our findings suggest that the previous consensus about the stability of $\mathrm{Ag}_{2} \mathrm{SNPs}$ in aquatic environments should be reconsidered.

\section{MATERIALS AND METHODS}

Materials. In the present study, the reagents except for the solid isotope $\mathrm{Ag}^{107}$ were purchased from Sigma-Aldrich. The $\mathrm{Ag}^{107}$ (99\%) was from Trace Sciences International (Delaware, USA), and it was dissolved by guaranteed reagent nitrate acid in an ultrasonic bath (KQ-600E, $40 \mathrm{kHz}, 600 \mathrm{~W}$ ) for $4 \mathrm{~h}$, followed by dilution with ultrapure water for $\mathrm{Ag}^{107} \mathrm{NO}_{3}$ preparation. The $\mathrm{Ag}_{2} \mathrm{SNPs}(34-91 \mathrm{~nm})$ with average size of $57.2 \pm 5.3 \mathrm{~nm}$ were prepared by the reaction of $\mathrm{AgNO}_{3}$ with elemental sulfur, which has been shown in our previous study. ${ }^{21}$ Briefly, $7.1 \mathrm{mg}$ sulfur, dissolved in $10 \mathrm{~mL}$ warm ethanol $\left(\sim 60{ }^{\circ} \mathrm{C}\right)$, was added dropwise to $\mathrm{AgNO}_{3}$ solution $(50 \mathrm{~mL}, 170 \mathrm{mg} / \mathrm{L})$ with $10 \mathrm{mg}$ PVP-40. The reaction was kept for $5 \mathrm{~h}$ at $95{ }^{\circ} \mathrm{C}$ under dark conditions, with a water-cooling system. The $\mathrm{Ag}_{2} \mathrm{SNPs}$ suspension was purified with five cycles of washing with ultrapure water using centrifugation (9384g, $30 \mathrm{~min}$ ), concentrated to approximately $150 \mathrm{mg} / \mathrm{L}$ and stored at $4{ }^{\circ} \mathrm{C}$ in the dark for later use. The $\mathrm{Ag}_{2}{ }^{107} \mathrm{SNPs}$, using $\mathrm{Ag}^{107} \mathrm{NO}_{3}$ as a precursor, were prepared using the above-mentioned process as well.

Characterization Analysis of NPs. The morphology of NPs in this study was observed on a JEOL JEM-2100F highresolution transmission electron microscope (HRTEM) at 200 $\mathrm{kV}$, and the elemental mapping of the imaged objects was characterized using an EDS detector (Oxford Inca, UK). The HRTEM samples were prepared by depositing $20 \mu \mathrm{L}$ aliquots of aqueous sample on the ultrathin carbon-coated copper grids, followed by drying in a vacuum desiccator. The silver ions collected with centrifugal filtration (Amicon Ultra-15, 3kD) at $9384 \mathrm{~g}$ for $15 \mathrm{~min}$, were quantified using inductively coupled plasma mass spectrometry (ICP-MS, Agilent 8800, USA). The XRD pattern of samples was measured by using a PANalytical X'Pert PRO diffractometer with $\mathrm{Cu} \mathrm{K} \alpha$ radiation $(\lambda=0.154$ $\mathrm{nm})$, with the diffraction angle $(2 \theta)$ from $10^{\circ}$ to $90^{\circ}$ at $0.0263^{\circ}$ per step. The NPs for XRD analysis were separated from solution by using centrifugal ultrafiltration (Amicon Ultra-15, $3 \mathrm{kD}$ ) and the pellet was precipitated dropwise on a glass slide, followed by drying in a vacuum desiccator. The surface morphologies of bulk $\mathrm{Ag}_{2} \mathrm{~S}$ particles were characterized on a Hitachi SU8020 FESEM at $3 \mathrm{kV}$ acceleration voltage and 5.2 $\mathrm{mm}$ working distance.

Transformations of $\mathrm{Ag}_{2}$ SNPs under Simulated Light. The transformations of $\mathrm{Ag}_{2} \mathrm{SNPs}$ in the presence of $\mathrm{Fe}$ (III) were performed under simulated light and in the dark, respectively. The experiments using simulated light exposure were conducted in a solar simulator with three air-cooled 2500 W Xe lamps (SN-500, Beifang Lihui, China). Quartz glass bottles $(100 \mathrm{~mL})$ with quartz caps were used in this study. The dark control experiment was performed in quartz glass bottles wrapped by four layers of aluminum foil and placed in the same solar simulator. The intensity of simulated light was set at 550 $\mathrm{W} / \mathrm{m}^{2}$, and the temperature was kept at $36 \pm 2{ }^{\circ} \mathrm{C}$ by using an air-cooling system. The $\mathrm{Ag}_{2} \mathrm{SNPs}$ stock solution was diluted by using $5 \mathrm{mM}$ borate buffer, followed by the addition of $\mathrm{Fe}(\mathrm{III})$ stock solution $(100 \mathrm{mg} / \mathrm{L})$ which was prepared by dissolving $\mathrm{Fe}\left(\mathrm{NO}_{3}\right)_{3} \cdot 9 \mathrm{H}_{2} \mathrm{O}$ in $2 \mathrm{mM} \mathrm{HNO}_{3}$, yielding a mixture of $5 \mathrm{mg} / \mathrm{L}$ $\mathrm{Ag}_{2} \mathrm{SNPs}$ and $2 \mathrm{mg} / \mathrm{L} \mathrm{Fe}$ (III). At each time interval $(0,4,10$, $18,24,48,72$, and $96 \mathrm{~h}$ ), a $10 \mathrm{~mL}$ aliquot of aqueous sample was taken from each quartz glass bottle. It should be noted that the solution was stirred to ensure homogeneity before sample collection. Centrifugal ultrafiltration (Ultra-15, 3kD, Millipore, $\mathrm{MA}$ ) at $9384 \mathrm{~g}$ for $15 \mathrm{~min}$ was used to collect the silver ions released from $\mathrm{Ag}_{2} \mathrm{SNPs}^{15}$ and pellets were collected for identification of particles by characterization analysis. The recovery efficiency of $1 \mathrm{mg} / \mathrm{L} \mathrm{AgNO}_{3}$ solution is $94.1 \pm 2.2 \%$, suggesting negligible loss of the analyte during the centrifugal ultrafiltration. All experiments were performed in triplicate.

Transformations of $\mathrm{Ag}_{2} \mathrm{SNPs}$ under Natural Sunlight. For experiments under natural sunlight, quartz glass bottles containing a mixture of $5 \mathrm{mg} / \mathrm{L} \mathrm{Ag}_{2} \mathrm{SNPs}$ and $2 \mathrm{mg} / \mathrm{L} \mathrm{Fe}(\mathrm{III})$ were placed in front of Building No. 3 in the Research Center for Eco-Environmental Sciences $\left(40^{\circ} 00^{\prime} 26.94^{\prime \prime} \mathrm{N}\right.$, $\left.116^{\circ} 20^{\prime} 15.10^{\prime \prime} \mathrm{E}\right)$, Chinese Academy of Sciences, Beijing, from the first to the eighth of July 2015 when it is continuously sunny, with a temperature between 18 and $34{ }^{\circ} \mathrm{C}$. The exposure to sunlight began near midday (11:00 a.m.) on July first. A total of $4 \mathrm{~mL}$ of aqueous sample was taken at 19:00 (the time of sundown in summer in Beijing) on July first, 5:00 (the time of sunrise in summer in Beijing) and 19:00 on July second, 5:00 and 9:00 on July third, 11:00 on July fourth, 12:00 noon on July fifth, 10:00 on July sixth, 11:00 on July seventh, and 11:00 on July eighth. Centrifugal ultrafiltration (Ultra-4, 3kD, Millipore, $\mathrm{MA}$ ) at $9384 \mathrm{~g}$ for $15 \mathrm{~min}$ was used to collect silver ions released from the $\mathrm{Ag}_{2} \mathrm{SNPs},{ }^{15}$ and pellets were collected for identification of particles by characterization analysis. All experiments were performed in triplicate.

Formation of $\mathrm{nAg}$ from $\mathrm{Ag}_{2} \mathrm{SNPs}$ in Natural Waters. Environmental water samples including landscape water, wastewater treatment plant effluent and river water were collected in Beijing by using polyvinyl chloride (PVC) containers $(2.5 \mathrm{~L})$, and all containers were rinsed 3-fold with the sample before they were filled up to volume. Samples were filtered through a $0.45 \mu \mathrm{m}$ glass fiber filter (Pall Corporation, $\mathrm{MI}$ ) and then spiked by stock $\mathrm{Ag}_{2} \mathrm{SNPs}$ and $\mathrm{Fe}(\mathrm{III})$, leading to concentrations of $5 \mathrm{mg} / \mathrm{L}$ and $2 \mathrm{mg} / \mathrm{L}$, respectively. Afterward, the samples were exposed to the light. Ten $\mathrm{mL}$ of sample was taken from each quartz glass bottle for identification of particles by characterization analysis.

Effect of Radical Scavengers on the Dissolution of $\mathrm{Ag}_{2}$ SNPs. To confirm the contribution of hydroxyl radical to photoinduced dissolution of $\mathrm{Ag}_{2} \mathrm{SNPs}$ in the presence of $\mathrm{Fe}(\mathrm{III})$, effects of radical scavengers such as tertiary butyl alcohol (TBA) and catalase on the $\mathrm{Ag}_{2} \mathrm{SNPs}$ dissolution were investigated. A catalase stock solution $(1000 \mathrm{U} / \mathrm{mL})$ from bovine liver or TBA $(20 \mathrm{mM})$ was added to the mixture of $\mathrm{Ag}_{2} \mathrm{SNPs}(5 \mathrm{mg} / \mathrm{L})$ and $\mathrm{Fe}(\mathrm{III})(2 \mathrm{mg} / \mathrm{L})$ to yield $300 \mathrm{U} / \mathrm{mL}$ catalase or $2 \mathrm{mM}$ TBA, respectively. These samples were exposed to the simulated light for $96 \mathrm{~h}$, and the samples were collected at $0,4,6,10,24,48,72$, and $96 \mathrm{~h}$, respectively, followed by determination of silver ions using ICP-MS.

Evidence for Formation of $\mathrm{nAg}$ from $\mathrm{Ag}_{2} \mathrm{SNPs}$. As the separation of low concentrations of $\mathrm{nAg}$ from $\mathrm{Ag}_{2} \mathrm{SNPs}$ is challenging, the mixture of $\mathrm{Fe}(\mathrm{III})$ and $\mathrm{Ag}_{2} \mathrm{SNPs}$ exposed to simulated light and in the dark for different time periods was ultracentrifuged ( $3 \mathrm{kDa}, 15 \mathrm{~min}, 9384 \mathrm{~g}$ ), respectively, and the pellet was washed with ultrapure water, followed by ultracentrifugation ( $3 \mathrm{kDa}, 15 \mathrm{~min}, 9384 \mathrm{~g}$ ) again to remove all remaining silver ions. Afterward, the purified pellet was incubated in $10 \mathrm{mM} \mathrm{H}_{2} \mathrm{O}_{2}$ for $20 \mathrm{~min}$ to dissolve silver particles, $^{22,23}$ and then the solution was ultracentrifuged ( 3 $\mathrm{kDa}, 15 \mathrm{~min}, 9384 \mathrm{~g}$ ) to collect the ultrafiltrate for ICP-MS measurements. The results of ICP-MS indicate the amount of 

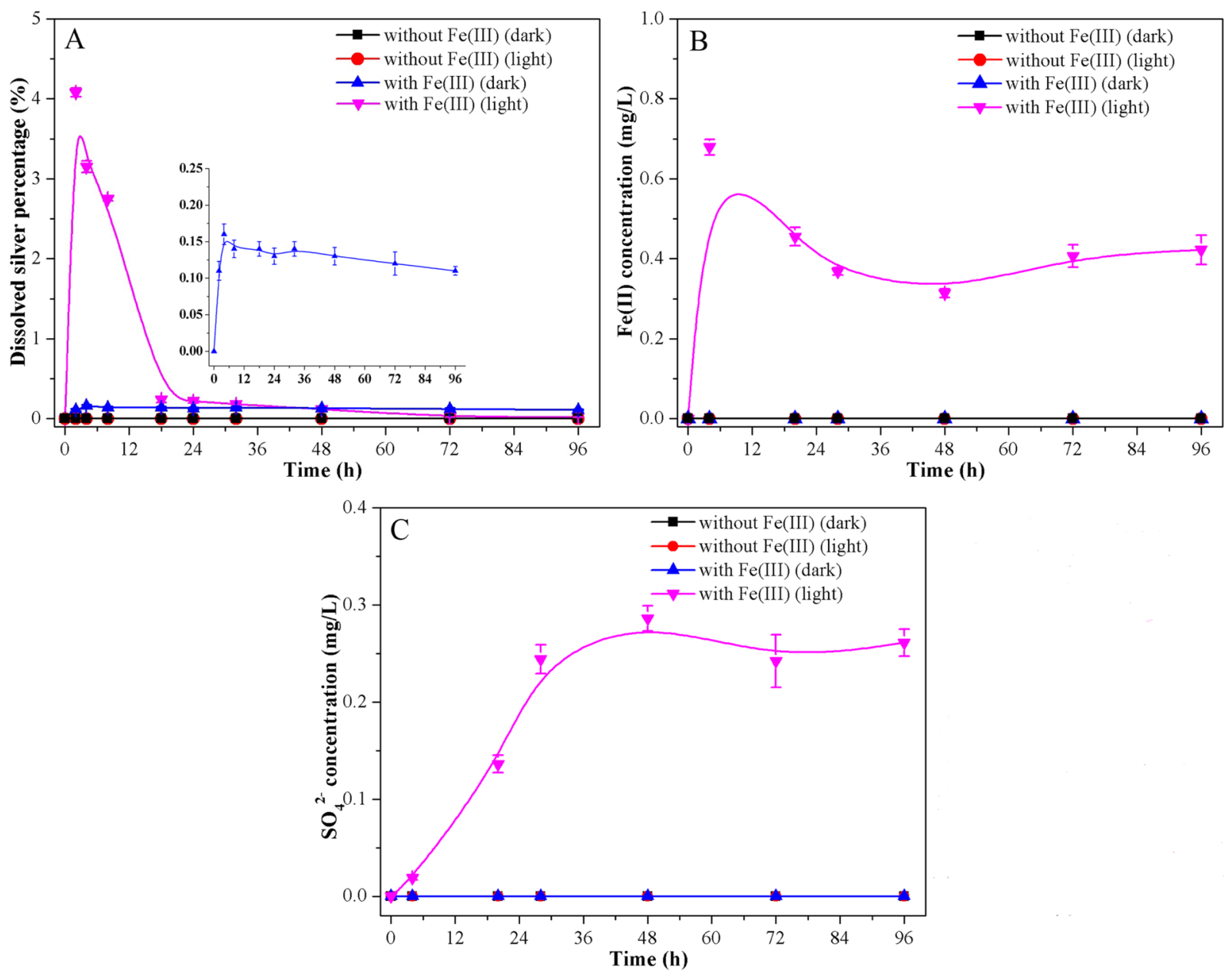

Figure 1. Kinetics of $\mathrm{Ag}_{2} \mathrm{SNPs}$ transformation in borate solution without or with $\mathrm{Fe}$ (III) under light and in the dark, respectively. (A) Dissolution kinetics of $\mathrm{Ag}_{2} \mathrm{SNPs}$, and inset is the amplification of the sample with $\mathrm{Fe}(\mathrm{III})$ in the dark. (B) Time-resolved concentrations of $\mathrm{Fe}(\mathrm{II})$ in the $\mathrm{Ag} \mathrm{S}_{2} \mathrm{SNPs}$ solution. $\mathrm{Fe}(\mathrm{II})$ is considered as the product of $\mathrm{Fe}(\mathrm{III})$ reduction when $\mathrm{Ag}_{2} \mathrm{SNPs}$ dissolution occurs under lighted conditions. (C) Time-resolved concentrations of $\mathrm{SO}_{4}{ }^{2-}$ in the $\mathrm{Ag}_{2} \mathrm{SNPs}$ solution. The occurrence of $\mathrm{SO}_{4}{ }^{2-}$ is observed in $\mathrm{Ag}_{2} \mathrm{SNPs}$ solution with $\mathrm{Fe}(\mathrm{III})$ under light conditions.

partial $\mathrm{nAg}$ which was dissolved by the $10 \mathrm{mM} \mathrm{H}_{2} \mathrm{O}_{2}$ during the period of $20 \mathrm{~min}$.

On the other hand, the ratio of $\mathrm{Ag}^{107}$ to $\mathrm{Ag}^{109}$ was investigated by using a mixture of commercial AgNPs (1 mg/ $\mathrm{L})$ and the synthesized $\mathrm{Ag}_{2}{ }^{107} \mathrm{SNPs}(5 \mathrm{mg} / \mathrm{L})$ in the presence of $\mathrm{Fe}(\mathrm{III})(2 \mathrm{mg} / \mathrm{L})$ under light conditions. The mixture was exposed to the simulated sunlight and $10 \mathrm{~mL}$ samples were collected at $0,4,10,24,48,72$, and 96 h, respectively. The samples were pretreated using the above-described method and the ultrafiltrates were measured by using ICP-MS. ${ }^{24}$ The value of the ratio of $\mathrm{Ag}^{107} / \mathrm{Ag}^{109}$ was calculated through comparison between counts per second (cps) of $\mathrm{Ag}^{107}$ and that of $\mathrm{Ag}^{109}$.

\section{RESULTS AND DISCUSSION}

$\mathrm{Fe}(\mathrm{III})$-Dependent Dissolution of $\mathrm{Ag}_{2} \mathrm{SNPs}$. The timeresolved concentration of silver ions is highly dependent on the occurrence of $\mathrm{Fe}(\mathrm{III})$ (Figure 1A); dissolution of $\mathrm{Ag}_{2} \mathrm{SNPs}$ is negligible in the absence of $\mathrm{Fe}$ (III) under light conditions or in the dark, while measurable concentrations of silver ions are observed in the $\mathrm{Ag}_{2} \mathrm{SNPs}$ solution with an environmentally relevant concentration of $\mathrm{Fe}$ (III) under both light and dark conditions. It is evident that $\mathrm{Fe}(\mathrm{III})$, one of the most abundant metals in terrestrial and aquatic environments, is a key factor controlling the dissolution of $\mathrm{Ag}_{2} \mathrm{SNPs}$. In the presence of
$\mathrm{Fe}(\mathrm{III})$, the amount of release of silver ion from $\mathrm{Ag}_{2} \mathrm{SNPs}$ under light irradiation $(\sim 4.1 \%)$ is an order of magnitude greater than that in the dark $(\sim 0.16 \%)$, indicating that light irradiation dramatically enhances the $\mathrm{Ag}_{2} \mathrm{SNPs}$ dissolution. Also, the concentration of silver ions remains constant after a small initial increase within the first $4 \mathrm{~h}$ in the dark, while a rapid increase within the first $4 \mathrm{~h}$ followed by a continuous decrease of silver ions for the next $20 \mathrm{~h}$ is observed in the light. This suggests that different pathways and mechanisms contribute to the $\mathrm{Ag}_{2} \mathrm{SNPs}$ dissolution process in the presence of $\mathrm{Fe}(\mathrm{III})$ depending on whether it occurs in the light or dark mode. Previous studies have already predicted potential dissolution of $\mathrm{Ag}_{2} \mathrm{SNPs}$ in the natural environment, ${ }^{25,26}$ although $\mathrm{Ag}_{2} \mathrm{~S}$ is considered as one of the most insoluble minerals. Here our findings demonstrated that $\mathrm{Ag}_{2} \mathrm{SNPs}$ could undergo dissolution in the water with an environmentally relevant concentration of $\mathrm{Fe}$ (III).

Sulfate, as well as $\mathrm{Fe}(\mathrm{II})$, the product of $\mathrm{Fe}(\mathrm{III})$ reduction, are detected under light conditions (Figure 1B,C). Given the thermodynamics of $\mathrm{Ag}$ and $\mathrm{Ag}_{2} \mathrm{SO}_{4}$, it was possible for the occurrence of $\mathrm{Ag}_{2} \mathrm{SO}_{4}$ when both $\mathrm{Ag}^{+}$and $\mathrm{SO}_{4}{ }^{2-}$ were simultaneously present in the solution. As shown in Figure $1 \mathrm{~A}$ and $\mathrm{B}$, comparable trends between silver ions and $\mathrm{Fe}(\mathrm{II})$ kinetics are observed. Both silver ions and $\mathrm{Fe}$ (II) reach highest levels at $4 \mathrm{~h}$, followed by continuous decreases until $24 \mathrm{~h}$ 

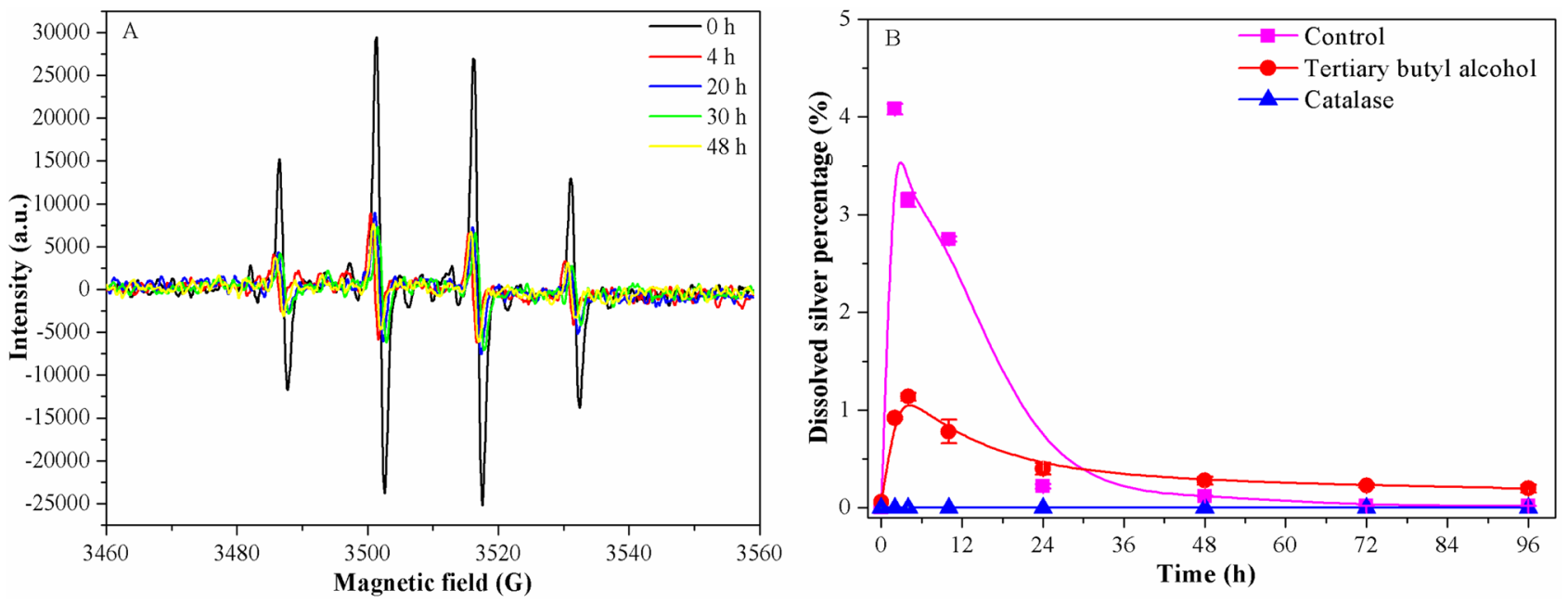

Figure 2. Role of hydroxyl radical on the dissolution of $\mathrm{Ag}_{2} \mathrm{SNPs}$ with $\mathrm{Fe}$ (III) under simulated light. (A) Time-resolved hydroxyl radical ESR signal (DMPO spin trap) induced by the mixture of $\mathrm{Ag}_{2} \mathrm{SNPs}$ and $\mathrm{Fe}(\mathrm{III})$ in the light. Note that $100 \mathrm{mM}$ DMPO in ultrapure water was used in this study. (B) Effect of radical scavengers on the dissolution of $\mathrm{Ag}_{2} \mathrm{SNPs}$.

elapsed. It is therefore assumed that the dramatic increase of silver ions in the light is related to the oxidation of $\mathrm{Ag}_{2} \mathrm{SNP}$. A recent publication reported that $\mathrm{O}_{3}$-induced $\mathrm{Ag}_{2} \mathrm{SNP}$ oxidation occurred in wastewater treatment plant effluent, where the release of silver ions and sulfate formation were observed. ${ }^{20}$ The hydroxyl radical, a powerful oxidant, can be generated during the reduction of $\mathrm{Fe}$ (III) to $\mathrm{Fe}$ (II) in the presence of light, ${ }^{27,28}$ which is confirmed through the stable spin adduct formed with 5,5-dimethyl-1-pyrroline $N$-oxide (DMPO) (Figure 2A). The level of the hydroxyl radical remains constant after a rapid decrease within the first $4 \mathrm{~h}$, which corresponds well to the rapid increase of silver ions and $\mathrm{Fe}$ (II) during the first $4 \mathrm{~h}$ in the light. Clearly, the hydroxyl radical likely contributes to the dramatic increase in silver ions under light conditions.

To further confirm whether the hydroxyl radical is the contributing factor to the dissolution of $\mathrm{Ag}_{2} \mathrm{SNPs}$ in the light, radical scavengers such as TBA or catalase were added to the $\mathrm{Ag}_{2} \mathrm{SNPs}$ solution. The $\mathrm{Ag}_{2} \mathrm{SNPs}$ dissolution is significantly inhibited after addition of TBA or catalase in the light (Figure $2 B$ ). The release of silver ions decreased from $\sim 4.1 \%$ to $\sim 1.1 \%$ when $2 \mathrm{mM}$ TBA was added to the $\mathrm{Ag}_{2} \mathrm{SNPs}$ solution, demonstrating that hydroxyl radical-based oxidation of $\mathrm{Ag}_{2} \mathrm{SNP}$ contributes to the dissolution of $\mathrm{Ag}_{2} \mathrm{SNP}$ in the presence of $\mathrm{Fe}(\mathrm{III})$ under light conditions. Moreover, catalase completely inhibits the $\mathrm{Ag}_{2} \mathrm{SNPs}$ dissolution in the presence of $\mathrm{Fe}(\mathrm{III})$ even under light conditions (Figure 2B). On account of these observations, we believe that the dramatic increase of silver ions in the light is mainly attributed to the oxidation of $\mathrm{Ag}_{2} \mathrm{SNP}$ due to the active hydroxyl radical formed during the reduction of $\mathrm{Fe}(\mathrm{III})$ to $\mathrm{Fe}(\mathrm{II})$ in water under light irradiation.

In the dark, however, we find the negligible effect of catalase on the dissolution of $\mathrm{Ag}_{2} \mathrm{SNPs}$ in the presence of $\mathrm{Fe}$ (III) (Figure S1). Moreover, given the negligible levels of $\mathrm{Fe}(\mathrm{II})$ and sulfate (Figure 1B,C), we postulate that cation exchange reactions (CERs) ${ }^{29-31}$ instead of the oxidation pathway may contribute to the occurrence of measurable silver ions in the dark. Exchange reactions between metallic ions and metal sulfides can occur due to the great differences in solubility of different metal sulfides. ${ }^{3,5,32,33}$ Indeed, both $\mathrm{Fe}(\mathrm{III})$ and $\mathrm{Hg}$ (II) can rapidly react and displace $\mathrm{Ag}(\mathrm{I})$ from $\mathrm{Ag}_{2} \mathrm{SNPs}$ (Figure S2) due to the much lower $K_{\text {sp }}$ values of $\mathrm{Fe}_{2} \mathrm{~S}_{3}\left(1.4 \times 10^{-88}\right)$ and $\mathrm{HgS}\left(2 \times 10^{-53}\right)$ than that of $\mathrm{Ag}_{2} \mathrm{~S}\left(K_{\mathrm{sp}}=8 \times 10^{-51}\right)$, resulting in the occurrence of measurable silver ions in the dark. In contrast, the dissolution of $\mathrm{Ag}_{2} \mathrm{SNPs}$ in the presence of $\mathrm{Cu}$ (II) or $\mathrm{Pb}(\mathrm{II})$ is negligible under dark conditions (Figure S2). This is understandable given the higher solubility of $\mathrm{CuS}\left(K_{\mathrm{sp}}=8 \times\right.$ $\left.10^{-37}\right)$ and $\mathrm{PbS}\left(K_{\mathrm{sp}}=3 \times 10^{-28}\right)$ than that of $\mathrm{Ag}_{2} \mathrm{~S}$. These results suggest that the CER between $\mathrm{Ag}(\mathrm{I})$ and $\mathrm{Fe}(\mathrm{III})$ is a potential mechanism for the $\mathrm{Fe}$ (III)-dependent dissolution of $\mathrm{Ag}_{2} \mathrm{SNPs}$ in the dark. Moreover, the increase in the release of silver ions from $\mathrm{Ag}_{2} \mathrm{SNPs}$ follow first order kinetics with rate constant $(k)$ of $1.06 \mathrm{~h}^{-1}$ (Figure S3).

Formation of $\mathbf{n A g}$ in the Light. Given the strong reducing capacity of $\mathrm{Fe}(\mathrm{II})$ and the comparable trend between silver ions and $\mathrm{Fe}(\mathrm{II})$ kinetics (Figure $1 \mathrm{~A}, \mathrm{~B}$ ), we postulate that the formation of $\mathrm{nAg}$ particles may contribute to the decrease in silver ions under light conditions. This assumption is validated by the observation of $\mathrm{nAg}$ particles between 15 and 30 $\mathrm{nm}$ in size in the $\mathrm{Ag}_{2} \mathrm{SNPs}$ solution after $24 \mathrm{~h}$ of light irradiation. The occurrence of $\mathrm{nAg}$ is clearly evidenced through the results of high resolution transmission electron microscopy (HRTEM) and energy-dispersive spectroscopy (EDS)(Figure $3 A-D)$. The lattice fringe spacing of $\sim 2.02 \AA$ is observed in the HRTEM image (Figure 3A), which corresponds to the $\{200\}$ plane of silver. ${ }^{34,35}$ Also, we examine the feasibility of $\mathrm{nAg}$ formation through the reaction between silver ions and $\mathrm{Fe}$ (II) in the light. Visible changes include the occurrence of silvery colloidal particles occur within $48 \mathrm{~h}$ in the light after mixing the silver nitrate and $\mathrm{Fe}(\mathrm{II})$. Moreover, both HRTEM-EDS analysis and the XRD spectrum provide robust evidence that silver ions are indeed able to be reduced to $\mathrm{nAg}$ by $\mathrm{Fe}(\mathrm{II})$ in the light (Figure S4).

We further performed silver isotope $\left(\mathrm{Ag}^{107}\right)$ experiments to examine the formation of $\mathrm{nAg}$ from $\mathrm{Ag}_{2} \mathrm{SNPs}$ under light conditions. According to previous studies, introduction of diluted $\mathrm{H}_{2} \mathrm{O}_{2}(10 \mathrm{mM})$ can effectively oxidize $\mathrm{nAg}$ to silver ions, while $\mathrm{Ag}_{2} \mathrm{~S}$ particles remain unchanged. ${ }^{22,23}$ As shown in Figure $4 \mathrm{~A}$, the mass of $\mathrm{nAg}$ dissolved by $10 \mathrm{mM} \mathrm{H}_{2} \mathrm{O}_{2}$ gradually increases from 0 to $6.8 \mu \mathrm{g}$ during the first $24 \mathrm{~h}$, after which little further increase occurs in the light, while there is no increase during the whole experimental time under dark conditions. It is 


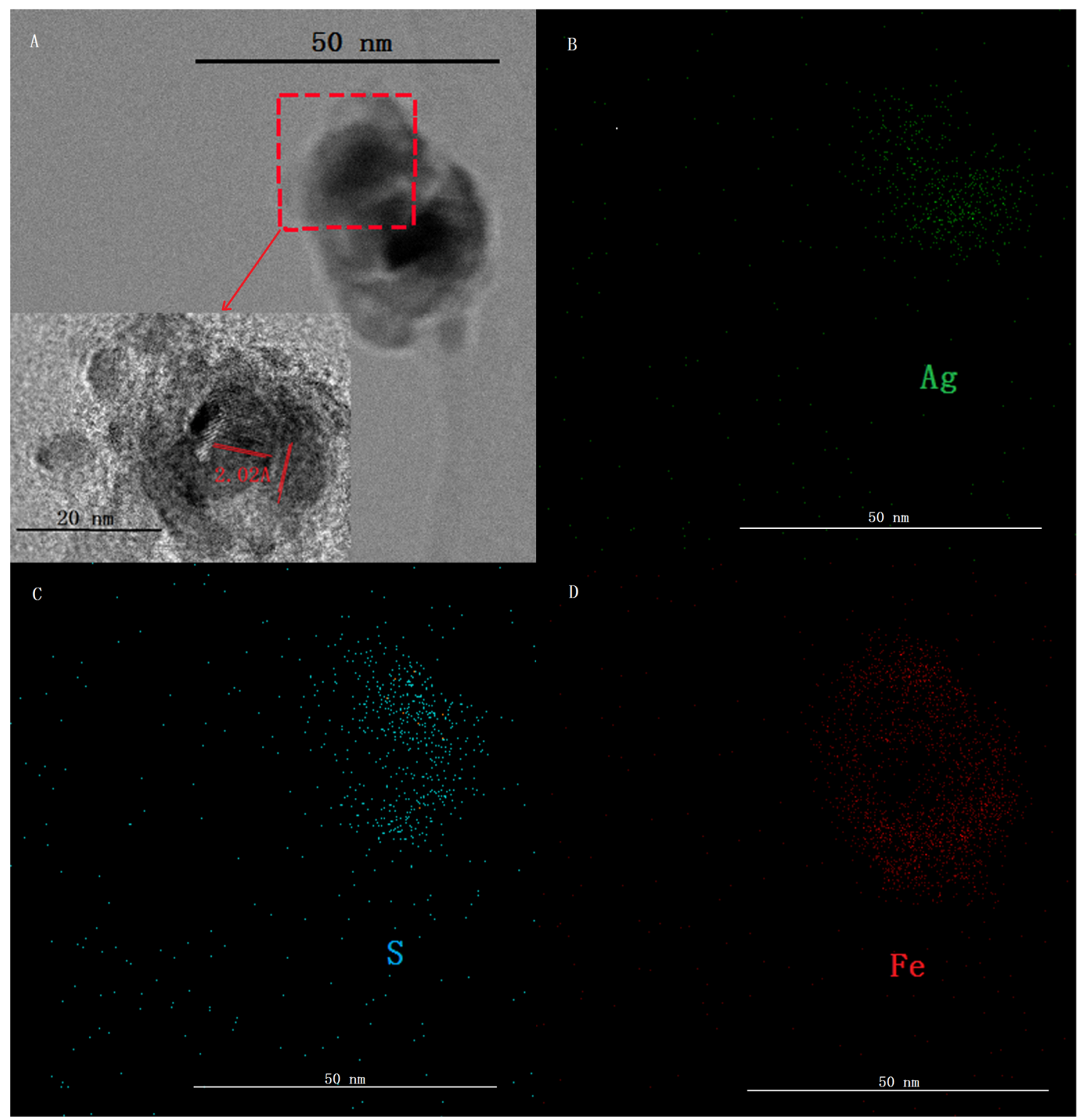

Figure 3. Identification of NPs after transformations of $\mathrm{Ag}_{2} \mathrm{SNPs}$ in borate solution with an environmentally relevant concentration of Fe(III) under simulated light. (A) TEM image. (B) HRTEM image of $\mathrm{nAg}$ with a lattice spacing of $2.02 \AA$. (C-E) EDS elemental mappings of the NPs after chemical transformations of $\mathrm{Ag}_{2} \mathrm{SNPs}$.

clear that $\mathrm{nAg}$ particles indeed form in the $\mathrm{Ag}_{2} \mathrm{SNPs}$ solution with $\mathrm{Fe}$ (III) under light conditions. On the other hand, the ratio of $\mathrm{Ag}^{107}$ to $\mathrm{Ag}^{109}$, calculated using their counts per second (cps) values from the inductively coupled plasma mass spectrometry (ICP-MS) measurements, maintains an equilibrium after a rapid increase by $2.6 \pm 0.9$ during the first $24 \mathrm{~h}$ in the light (Figure 4B). However, a negligible increase is observed during $96 \mathrm{~h}$ for the pure commercial $\mathrm{nAg}\left(\mathrm{Ag}^{107} /\right.$ $\mathrm{Ag}^{109}$ ratio: $1.07^{36,37}$ ) (Figure $4 \mathrm{~B}$ ). This finding demonstrates the occurrence of $\mathrm{nAg}^{107}$ in the solution containing both $\mathrm{Ag}_{2}{ }^{107} \mathrm{SNPs}$ and commercial AgNPs under light conditions. Also, the $\mathrm{Ag}^{107}$ of $\mathrm{nAg}^{107}$ derives from the $\mathrm{Ag}_{2}{ }^{107} \mathrm{SNPs}$, so this provides robust evidence for the formation of $\mathrm{nAg}$ from $\mathrm{Ag}_{2}$ SNPs in the presence of $\mathrm{Fe}$ (III) in the light.

We also found that these new AgNPs formed probably would not be oxidized back to $\mathrm{Ag}^{+}$even in the light for long time. As shown in Figure $\mathrm{S} 5$, it is evident that $\mathrm{Ag}^{+}$concentration increased within the first $4 \mathrm{~h}$ followed by a decrease for the next
$20 \mathrm{~h}$, and then the $\mathrm{Ag}^{+}$level remains constant for the next 268 h. This might be attributed to the stabilization of iron coating adsorbed on the surface of these new AgNPs, which could be observed in the HRTEM images (Figure 3). However, the concentration of $\mathrm{Ag}^{+}$would rapidly increased again when we added a second equivalent of $\mathrm{Fe}$ (III) to the solution, demonstrating the great role of $\mathrm{Fe}(\mathrm{III})$ in the transformation of $\mathrm{Ag}_{2} \mathrm{SNPs}$ in water.

Transformations of $\mathrm{Ag}_{2} \mathrm{SNPs}$ in Natural Sunlight. The transformations of $\mathrm{Ag}_{2} \mathrm{SNPs}$ were examined in the presence of $\mathrm{Fe}(\mathrm{III})$ under natural sunlight. Figure $\mathrm{S} 6$ shows the dissolution kinetics of $\mathrm{Ag}_{2}$ SNPs in borate solution with an environmentally relevant concentration of $\mathrm{Fe}(\mathrm{III})$ under sunlight. The results indicated that the dissolution of $\mathrm{Ag}_{2} \mathrm{SNPs}$ in the presence of $\mathrm{Fe}$ (III) can indeed occur in the daytime, while the concentration of silver ions remains constant in the night (Figure S6). This agrees well with the results observed in the laboratory. The extent of $\mathrm{Ag}_{2} \mathrm{SNPs}$ dissolution under natural 

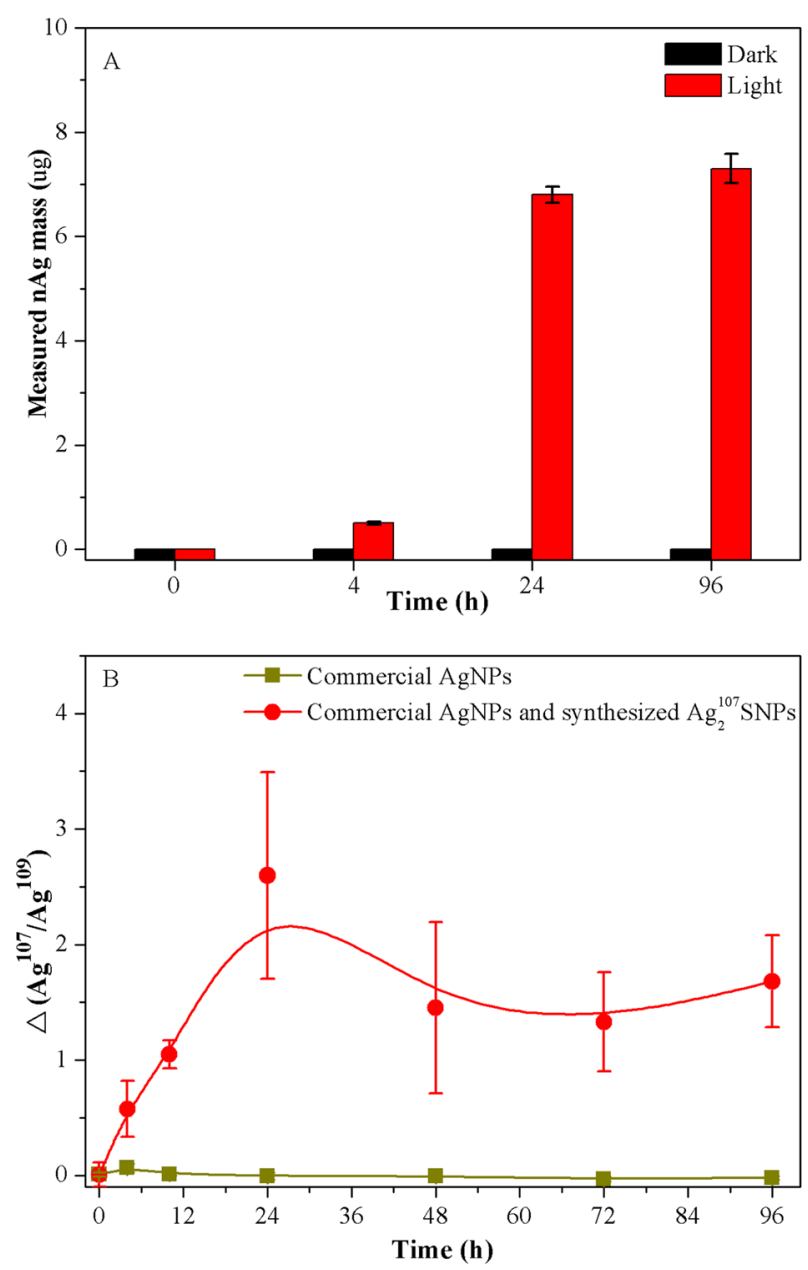

Figure 4. Evidence supports the formation of silver particles from $\mathrm{Ag}_{2} \mathrm{SNPs}$ in the presence of $\mathrm{Fe}(\mathrm{III})$ under lighted conditions. (A) Measured mass of silver particles dissolved with $10 \mathrm{mM} \mathrm{H}_{2} \mathrm{O}_{2}$ at room temperature for $20 \mathrm{~min}$. (B) The change in time-resolved $\mathrm{Ag}^{107} / \mathrm{Ag}^{109}$ of commercial AgNPs $(1 \mathrm{mg} / \mathrm{L})$ and commercial AgNPs $(1 \mathrm{mg} / \mathrm{L})$ with synthesized $\mathrm{Ag}_{2}{ }^{107} \mathrm{SNPs}(5 \mathrm{mg} / \mathrm{L})$ in the presence of $\mathrm{Fe}(\mathrm{III})$ (2 $\mathrm{mg} / \mathrm{L})$ under lighted conditions, respectively. The value of $\mathrm{Ag}^{107} / \mathrm{Ag}^{109}$ is calculated through comparison between counts per second (cps) of $\mathrm{Ag}^{107}$ and those of $\mathrm{Ag}^{109}$, and the $\Delta\left(\mathrm{Ag}^{107} / \mathrm{Ag}^{109}\right)$ shown is obtained through subtraction of the value of $\mathrm{Ag}^{107} / \mathrm{Ag}^{109}$ at $0 \mathrm{~h}$.

sunlight is $\sim 10.9 \%$, being far greater than that under simulated light in the laboratory. This significant difference can likely be attributed to the role of ultraviolet light; compared containers made of quartz glass, the extent of dissolution of $\mathrm{Ag}_{2} \mathrm{SNPs}$ in normal glass bottles is clearly low under natural sunlight (Figure S7).

The HRTEM and EDS elemental mapping analysis confirm the presence of $\mathrm{nAg}$ in the $\mathrm{Ag}_{2} \mathrm{SNPs}$ solution containing an environmentally relevant concentration of $\mathrm{Fe}$ (III) under natural sunlight conditions (Figure S8), documenting the potential formation of $\mathrm{nAg}$ from $\mathrm{Ag}_{2} \mathrm{SNPs}$ in the ambient environment.

Formation of $\mathrm{nAg}$ from $\mathrm{Ag}_{2} \mathrm{SNPs}$ in Natural Waters. The formation of $\mathrm{nAg}$ from $\mathrm{Ag}_{2} \mathrm{SNPs}$ is further examined by using natural waters such as landscape water, wastewater treatment plant effluent and river water. Here the formation of $\mathrm{nAg}$ particles is evidenced through the HRTEM and EDS (Figure 5 and Figures S9, S10). Clearly, these results indicate that photoinduced formation of $\mathrm{nAg}$ from $\mathrm{Ag}_{2} \mathrm{SNPs}$ in the presence of $\mathrm{Fe}(\mathrm{III})$ may occur widely in aquatic environments, suggesting a potential natural source of $\mathrm{nAg}$ in the nature environment. Measurable $\mathrm{Fe}$ (III) have been reported in some surface waters, ${ }^{38,39}$ so the formation of $\mathrm{nAg}$ from $\mathrm{Ag}_{2} \mathrm{SNPs}$ must be taken into account when considering the fate of $\mathrm{nAg}$ in natural environments.

Pathway of $\mathrm{Fe}$ (III)-Dependent Transformations of $\mathrm{Ag}_{2}$ SNPs in Water. Figure 6 summarizes the potential pathway of $\mathrm{Fe}$ (III)-dependent transformations of $\mathrm{Ag}_{2} \mathrm{SNPs}$ in water. In the light, hydroxyl radical can be generated during the reduction of $\mathrm{Fe}$ (III) to $\mathrm{Fe}(\mathrm{II})$ in water, ${ }^{27,28}$ mainly contributing to the significant release of silver ions from $\mathrm{Ag}_{2} \mathrm{SNPs}$. The silver ions thus released are gradually reduced to $\mathrm{nAg}$ by $\mathrm{Fe}(\mathrm{II})$. These combined results allow us to propose that the formation of $\mathrm{nAg}$ from $\mathrm{Ag}_{2} \mathrm{SNPs}$ in the presence of $\mathrm{Fe}$ (III) under light conditions may proceed through a two-step reaction mechanism, the photoinduced and $\mathrm{Fe}$ (III)-dependent dissolution of $\mathrm{Ag}_{2} \mathrm{SNPs}$, followed by the reduction of silver ions to $\mathrm{nAg}$ by $\mathrm{Fe}$ (II) (eqs 1-3).

$$
\begin{aligned}
& \mathrm{Fe}^{3+}+\mathrm{H}_{2} \mathrm{O} \stackrel{h v}{\rightarrow} \mathrm{Fe}^{2+}+\cdot \mathrm{OH}+\mathrm{H}^{+} \\
& 2 \mathrm{Ag}_{2} \mathrm{~S}+4 \cdot \mathrm{OH}+3 \mathrm{O}_{2} \stackrel{h v}{\rightarrow} 4 \mathrm{Ag}^{+}+2 \mathrm{H}_{2} \mathrm{O}+2 \mathrm{SO}_{4}^{2-} \\
& \mathrm{Ag}^{+}+\mathrm{Fe}^{2+} \stackrel{h v}{\rightarrow} \mathrm{Ag}^{0}+\mathrm{Fe}^{3+}
\end{aligned}
$$

The photoreduction of $\mathrm{Fe}$ (III) (eq 1) in the light produces the hydroxyl radical, ${ }^{27,40,41}$ which enables the dissolution of $\mathrm{Ag}_{2}$ SNPs and generation of sulfate (eq 2), ${ }^{42,43}$ along with a remarkable decrease in dissolved oxygen (Figure S11). The silver ions are reduced to $\mathrm{nAg}$ by $\mathrm{Fe}$ (II) in the light (eq 3). These results provide robust evidence to support the proposed reaction mechanism that photoinduced $\mathrm{Fe}$ (II, III) redox cycling drives the formation of $\mathrm{nAg}$ from $\mathrm{Ag}_{2} \mathrm{SNPs}$ in water.

In the dark, we propose that silver is remobilized from $\mathrm{Ag}_{2}$ SNPs through the CER between $\mathrm{Fe}(\mathrm{III})$ and $\mathrm{Ag}(\mathrm{I})$ of $\mathrm{Ag}_{2} \mathrm{SNPs}$. Its pathway is not currently understood, but may be related to the formation of $\mathrm{Fe}_{2} \mathrm{~S}_{3}$ that tends to be unstable and decomposes to $\mathrm{FeS},{ }^{42,44}$ followed by the second CER between $\mathrm{FeS}$ and the released silver ions to reform $\mathrm{Ag}_{2} \mathrm{SNPs}^{21}$ When the CERs maintain an equilibrium within a short time, the concentration of silver ions remains constant.

Environmental Implications. Previous studies have already shown that dissolved silver mainly controls the toxicity of particles containing silver to organisms. ${ }^{15,45}$ Our findings suggest that $\mathrm{Ag}_{2} \mathrm{SNPs}$ safety may be overestimated in past studies, even though the released silver ions subsequently decrease due to the formation of $\mathrm{nAg}$. The rapid increase of silver ions release from $\mathrm{Ag}_{2} \mathrm{SNPs}$ during the initial stage of light exposure indicates that acute toxicity of $\mathrm{Ag}_{2} \mathrm{SNPs}$ in $\mathrm{Fe}(\mathrm{III})$ present environments may occur. The transformation processes especially dissolution, therefore, potentially affect the hazard of $\mathrm{Ag}_{2} \mathrm{SNPs}$, which should be taken into account when assessing their risks to aquatic ecosystems. In general, $\mathrm{Ag}_{2} \mathrm{SNPs}$ are mainly in sludge of wastewater treatment plant. ${ }^{25}$ The main pathway by which $\mathrm{Ag}_{2} \mathrm{SNPs}$ enter natural environment is via application of sludge to soils, since erosion could release $\mathrm{Ag}_{2} \mathrm{SNPs}$ to stream, rivers and lakes. A buildup of $\mathrm{Ag}_{2} \mathrm{SNPs}$ in surface waters will raise concern about their potential hazards associated with transformations.

Our findings provide information for further understanding the environmental fate of $\mathrm{nAg}$ as well as for discovering a potential source of naturally occurring $\mathrm{nAg}$ in aquatic environment. The $\mathrm{nAg}$ particles, formed from $\mathrm{Ag}_{2} \mathrm{SNPs}$, show 


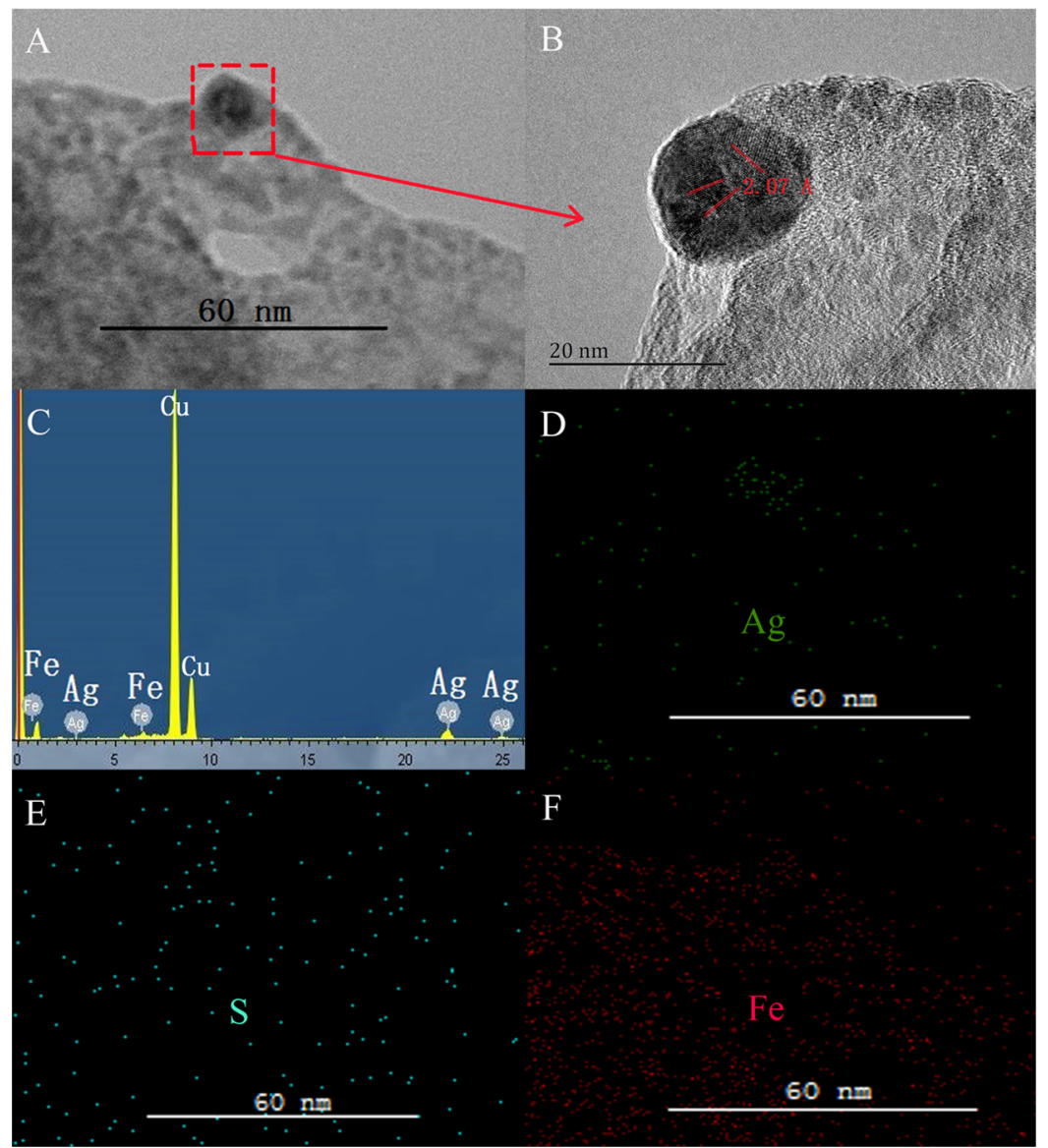

Figure 5. HRTEM images of NPs after transformations of $\mathrm{Ag}_{2} \mathrm{SNPs}$ in landscape water with $\mathrm{Fe}$ (III) under light. (A) HRTEM image. (B) nAg with a lattice spacing of $2.07 \AA$. (C) EDS image of the $\mathrm{nAg}$ particle in (B), and the presence of $\mathrm{Cu}$ peaks is attributed to the ultrathin carbon-coated copper grids for HRTEM analysis. (D-F) EDS elemental mappings of the nAg shown in Figure 4B.

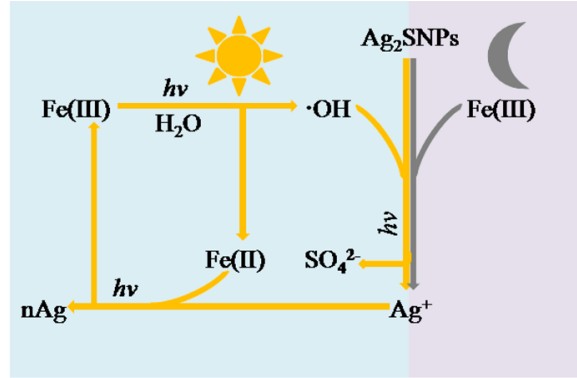

Figure 6. Pictorial summary of the proposed pathway of $\mathrm{Fe}(\mathrm{III})$ dependent transformations of $\mathrm{Ag}_{2} \mathrm{SNPs}$ in water.

far smaller size than $\mathrm{Ag}_{2} \mathrm{SPs}$, which will inevitably influence their transport in the natural environments, as previous study has shown that coexisted particles can influence behavior of NPs. ${ }^{46,47}$ Moreover, the nAg can likely deliver much farther distances in the natural environments, since a recent study documented that small particles always show greater mobility than big particles. ${ }^{48}$ Taken together, the real risks of $\mathrm{Ag}_{2}$ SNPs in natural waters must be more comprehensively re-evaluated in future studies, especially for the hazard of forming $\mathrm{nAg}$ particles.

\section{ASSOCIATED CONTENT}

S Supporting Information

The Supporting Information is available free of charge on the ACS Publications website at DOI: 10.1021/acs.est.6b04042.

Additional details of results (PDF)

\section{AUTHOR INFORMATION}

\section{Corresponding Author}

*Phone: +86 10 62849124; fax: +86 10 62849339; e-mail: ywwang@rcees.ac.cn.

\section{Notes}

The authors declare no competing financial interest.

\section{ACKNOWLEDGMENTS}

We thank the National Natural Science Foundation of China (21222702, 21137002), Strategic Priority Research Program of the Chinese Academy of Science (XDB14010400) and the China Postdoctoral Science Foundation (2014M560124, 2015T80141) for financial support.

\section{REFERENCES}

(1) Benn, T. M.; Westerhoff, P. Nanoparticle silver released into water from commercially available sock fabrics. Environ. Sci. Technol. 2008, 42, 4133-4139.

(2) Glover, R. D.; Miller, J. M.; Hutchison, J. E. Generation of metal nanoparticles from silver and copper objects: nanoparticle dynamics 
on surfaces and potential sources of nanoparticles in the environment. ACS Nano 2011, 5, 8950-8957.

(3) Liu, J.; Sonshine, D. A.; Shervani, S.; Hurt, R. H. Controlled release of biologically active silver from nanosilver surfaces. ACS Nano 2010, 4, 6903-6913.

(4) Levard, C.; Hotze, E. M.; Lowry, G. V., Jr.; Brown, G. E. Environmental transformations of silver nanoparticles: impact on stability and toxicity. Environ. Sci. Technol. 2012, 46, 6900-6914.

(5) Thalmann, B.; Voegelin, A.; Sinnet, B.; Morgenroth, E.; Kaegi, R. Sulfidation kinetics of silver nanoparticles reacted with metal sulfides. Environ. Sci. Technol. 2014, 48, 4885-4892.

(6) Kent, R. D.; Oser, J. G.; Vikesland, P. J. Controlled evaluation of silver nanoparticle sulfidation in a full-scale wastewater treatment plant. Environ. Sci. Technol. 2014, 48, 8564-8572.

(7) Levard, C.; Reinsch, B. C.; Michel, F. M.; Oumahi, C.; Lowry, G. V., Jr.; Brown, G. E. Sulfidation processes of PVP-coated silver nanoparticles in aqueous solution: impact on dissolution rate. Environ. Sci. Technol. 2011, 45, 5260-5266.

(8) Lowry, G. V.; Espinasse, B. P.; Badireddy, A. R.; Richardson, C. J.; Reinsch, B. C.; Bryant, L. D.; Bone, A. J.; Deonarine, A.; Chae, S.; Therezien, M.; Colman, B. P.; Hsu-Kim, H.; Bernhardt, E. S.; Matson, C. W.; Wiesner, M. R. Long-term transformation and fate of manufactured $\mathrm{Ag}$ nanoparticles in a simulated large scale freshwater emergent wetland. Environ. Sci. Technol. 2012, 46, 7027-7036.

(9) Kim, B.; Park, C.; Murayama, M., Jr.; Hochella, M. F. Discovery and characterization of silver sulfide nanoparticles in final sewage sludge products. Environ. Sci. Technol. 2010, 44, 7509-7514.

(10) Donner, E.; Scheckel, K.; Sekine, R; Popelka-Filcoff, R. S.; Bennett, J. W.; Brunetti, G.; Naidu, R.; McGrath, S. P.; Lombi, E. Nonlabile silver species in biosolids remain stable throughout 50 years of weathering and ageing. Environ. Pollut. 2015, 205, 78-86.

(11) Sekine, R.; Khaksar, M.; Brunetti, G.; Donner, E.; Scheckel, K. G.; Lombi, E.; Vasilev, K. Surface immobilization of engineered nanomaterials for in situ study of their environmental transformations and fate. Environ. Sci. Technol. 2013, 47, 9308-9316.

(12) Sekine, R.; Bruneti, G.; Donner, E.; Khaksar, M.; Vasilev, K.; Jamting, A. K.; Scheckel, K. G.; Kappen, P.; Zhang, H.; Lombi, E. Speciation and lability of $\mathrm{Ag}$-, $\mathrm{AgCl}-$, and $\mathrm{Ag}_{2} \mathrm{~S}$-nanoparticles in soil determined by $\mathrm{X}$-ray absorption spectroscopy and diffusive gradients in thin films. Environ. Sci. Technol. 2015, 49, 897-905.

(13) Khaksar, M.; Jolley, D. F.; Sekine, R.; Vasilev, K.; Johannessen, B.; Donner, E.; Lombi, E. In situ chemical transformations of silver nanoparticles along the water-sediment continuum. Environ. Sci. Technol. 2015, 49, 318-325.

(14) Reinsch, B. C.; Levard, C.; Li, Z.; Ma, R.; Wise, A.; Gregory, K. B., Jr.; Brown, G. E.; Lowry, G. V. Sulfidation of silver nanoparticles decrease Escherichia coli growth inhibition. Environ. Sci. Technol. 2012, 46, 6992-7000.

(15) Levard, C.; Hotze, E. M.; Colman, B. P.; Dale, A. L.; Truong, L.; Yang, X. Y.; Bone, A. J., Jr.; Brown, G. E.; Tanguay, R. L.; Di Giulio, R. T.; Bernhardt, E. S.; Meyer, J. N.; Wiesner, M. R.; Lowry, G. V. Sulfidation of silver nanoparticles: natural antidote to their toxicity. Environ. Sci. Technol. 2013, 47, 13440-13448.

(16) Lombi, E.; Donner, E.; Taheri, S.; Tavakkoli, E.; Jamting, A. K.; McClure, S.; Naidu, R.; Miller, B. W.; Scheckel, K. G.; Vasilev, K. Transformation of four silver/silver chloride nanoparticles during anaerobic treatment of wastewater and post-processing of sewage sludge. Environ. Pollut. 2013, 176, 193-197.

(17) Liu, J.; Jiang, G. Silver Nanoparticles in the Environment; Springer-Verlag: Berlin Heidelberg, 2015.

(18) Fabrega, J.; Luoma, S. N.; Tyler, C. R.; Galloway, T. S.; Lead, J. R. Silver nanoparticles: behaviour and effects in the aquatic environment. Environ. Int. 2011, 37, 517-531.

(19) Nowack, B. Nanosilver revisted downstream. Science 2010, 330, $1054-1055$.

(20) Thalmann, B.; Voegelin, A.; von Gunten, U.; Behra, R.; Morgenroth, E.; Kaegi, R. Effect of ozone treatment on nano-sized silver sulfide in wastewater effluent. Environ. Sci. Technol. 2015, 49, 10911-10919.
(21) Li, L.; Wang, Y.; Liu, Q.; Jiang, G. Rethinking stability of silver sulfide nanoparticles in the aquatic environment: photoinduced transformation of $\mathrm{Ag}_{2} \mathrm{~S}-\mathrm{NPs}$ in the presence of $\mathrm{Fe}(\mathrm{III})$. Environ. Sci. Technol. 2016, 50, 188-196.

(22) Tsogas, G. Z.; Giokas, D. L.; Vlessidis, A. G. Ultratrace determination of silver, gold, and iron oxide nanoparticles by micelle mediated preconcentration/selective back-extraction coupled with flow injection chemiluminescence detection. Anal. Chem. 2014, 86, 3484-3492.

(23) Tan, Z.; Liu, J.; Guo, X.; Yin, Y.; Byeon, S. K.; Moon, M. H.; Jiang, G. Toward full spectrum speciation of silver nanoparticles and ionic silver by on-line coupling of hollow fiber flow field-flow fractionation and minicolumn concentration with multiple detectors. Anal. Chem. 2015, 87, 8441-8447.

(24) Malysheva, A.; Lombi, E.; Voelcker, N. H. Bridging the divide between human and environmental nanotoxicology. Nat. Nanotechnol. 2015, 10, 835-844.

(25) Kim, B.; Park, C.; Murayama, M.; Hochella, M. F., Jr. Discovery and characterization of silver sulfide nanoparticles in final sewage sludge products. Environ. Sci. Technol. 2010, 44, 7509-7514.

(26) Colman, B. P.; Arnaout, C. L.; Anciaux, S.; Gunsch, C. K.; Hochella, M. F., Jr.; Kim, B.; Lowry, G. V.; McGill, B. M.; Reinsch, B. C.; Richardson, C. J.; Unrine, J. M.; Wright, J. P.; Yin, L.; Bernhardt, E. $\mathrm{S}$. Low concentrations of silver nanoparticles in biosolids cause adverse ecosystem responses under realistic field scenario. PLoS One 2013, 8, e57189.

(27) Liu, D.; Xiu, Z.; Liu, F.; Wu, G.; Adamson, D.; Newell, C.; Vikesland, P.; Tsai, A.; Alvarez, P. J. Perfluorooctanoic acid degradation in the presence of $\mathrm{Fe}$ (III) under natural sunlight. J. Hazard. Mater. 2013, 262, 456-463.

(28) Liu, X.; Wu, F.; Deng, N. Photoproduction of hydroxyl radicals in aqueous solution with algae under high-pressure mercury lamp. Environ. Sci. Technol. 2004, 38, 296-299.

(29) Wark, S. E.; Hsia, C.; Son, D. H. Effects of ion solvation and volume change of reaction on the equilibrium and morhphology in cation-exchange reaction of nanocrystals. J. Am. Chem. Soc. 2008, 130, 9550-9555.

(30) Powell, A. E.; Hodges, J. M.; Schaak, R. E. Preserving both anion and cation sublattice features during a nanocrystal cation-exchange reaction: synthesis of metastable wurtzite-type $\mathrm{CoS}$ and $\mathrm{MnS}$. J. Am. Chem. Soc. 2016, 138, 471-474.

(31) Huang, K.; Xu, K.; Tang, J.; Yang, L.; Zhou, J.; Hou, X.; Zheng, C. Room temperature cation exchange reaction in nanocrystals for ultrasensitive speciation analysis of silver ions and silver nanoparticles. Anal. Chem. 2015, 87, 6584-6591.

(32) Bell, R. A.; Kramer, J. R. Structural chemistry and geochemistry of silver-sulfur compounds: critical review. Environ. Toxicol. Chem. 1999, 18, 9-22.

(33) Oudar, J. Sulphur-metal interactions. Mater. Sci. Eng. 1980, 42, 101-109.

(34) Agnihotri, S.; Mukherji, S.; Mukherji, S. Size-controlled silver nanoparticles synthesized over the range 5-100 nm using the same protocol and their antibacterial efficacy. RSC Adv. 2014, 4, 39743983.

(35) Wu, Y. A.; Li, L.; Li, Z.; Kinaci, A.; Chan, M. K. Y.; Sun, Y.; Guest, J. R.; McNulty, I.; Rajh, T.; Liu, Y. Visualizing redox dynamics of a single $\mathrm{Ag} / \mathrm{AgCl}$ heterogeneous nanocatalyst at atomic resolution. ACS Nano 2016, 10, 3738-3746.

(36) Luo, Y.; Dabek-Zlotorzynska, E.; Celo, V.; Muir, D. C. G.; Yang, $\mathrm{L}$. Accurate and precise determination of silver isotope fractionation in environmental samples by multicollector-ICPMS. Anal. Chem. 2010, 82, 3922-3928.

(37) Laycock, A.; Stolpe, B.; Römer, I.; Dybowska, A.; Valsami-Jones, E.; Lead, J. R.; Rehkämper, M. Synthesis and characterization of isotopically labeled silver nanoparticles for tracing studies. Environ. Sci.: Nano 2014, 1, 271-283.

(38) Conway, T. M.; John, S. G. Quantification of dissolved iron sources to the North Atlantic ocean. Nature 2014, 511, 212-215. 
(39) Hawkings, J. R.; Wadham, J. L.; Tranter, M.; Raiswell, R.; Benning, L. G.; Statham, P. L.; Tedstone, A.; Nienow, P.; Lee, K.; Telling, J. Ice sheets as a significant source of highly reactive nanoparticulate iron to the oceans. Nat. Commun. 2014, 5, DOI: $10.1038 /$ ncomms 4929 .

(40) Tokumura, M.; Morito, R.; Hatayama, R.; Kawase, Y. Iron redox cycling in hydroxyl radical generation during the photo-Fenton oxidative degradation: dynamic change of hydroxyl radical concentration. Appl. Catal., B 2011, 106, 565-576.

(41) Burns, J. M.; Craig, P. S.; Shaw, T. J.; Ferry, J. L. Multivariate examination of $\mathrm{Fe}(\mathrm{II}) / \mathrm{Fe}$ (III) cycling and consequent hydroxyl radical generation. Environ. Sci. Technol. 2010, 44, 72276-7231.

(42) Sand, W.; Gehrke, T.; Jozsa, P.; Schippers, A. (Bio)chemistry of bacterial leaching-direct vs. indirect bioleaching. Hydrometallurgy 2001, 59, 159-175.

(43) Schippers, A.; Sand, W. Bacterial leaching of metal sulfides proceeds by two indirect mechanisms via thiosulfate or via polysulfides and sulfur. Appl. Environ. Microbiol. 1999, 65, 319-321.

(44) Adams, N. W. H.; Kramer, J. R. Reactivity of silver(I) ion with thiol ligands in the presence of iron sulfide. Environ. Toxicol. Chem. 1998, 17, 625-629.

(45) Ivask, A.; ElBadawy, A.; Kaweeteerawat, C.; Boren, D.; Fischer, H.; Ji, Z.; Chang, C. H.; Tolaymat, T.; Telesca, D.; Zink, J. I.; Cohen, Y.; Holden, P. A.; Godwin, H. A. Toxicity mechanisms in Escherichia coli vary for silver nanoparticles and differ from ionic silver. ACS Nano 2014, 8, 374-386.

(46) Jiang, C.; Aiken, G. R.; Hsu-Kim, H. Effects of natural organic matter properties on the dissolution kinetics of zinc oxide nanoparticles. Environ. Sci. Technol. 2015, 49, 11476-11484.

(47) Yang, X.; Lin, S.; Wiesner, M. R. Influence of natural organic matter on transport and retention of polymer coated silver nanoparticles in porous media. J. Hazard. Mater. 2014, 264, 161-168. (48) Ren, D.; Smith, J. A. Retention and transport of silver nanoparticles in a ceramic porous medium used for point-of-use water treatment. Environ. Sci. Technol. 2013, 47, 3825-3832. 